Endocrinol. Japon. 1989, 36 (1), 147-154

\title{
NOTE
}

\section{Comparative in vivo and in vitro Studies on Abnormal GH Secretion in Patients with Acromegaly}

\author{
Shozo OHGO $^{1}$, Emi ISHIKAWA ${ }^{1}$, Kuninobu NAKATSURU ${ }^{1}$, \\ KAZUO KINOSHITA ${ }^{2}$ AND SHIGERU MATSUKURA ${ }^{1}$
}

\author{
${ }^{1}$ Third Division, Department of Medicine, and ${ }^{2}$ Department of \\ Neurosurgery Miyazaki Medical College \\ 5200, Kihara, Kiyotake, Miyazaki, 889-16, Japan
}

\begin{abstract}
Eight patients with active acromegaly due to GH-producing pituitary adenoma were studied. GH secretory dynamics in vitro was evaluated by adding GRF, CRF, or a somatostatin analog, SMS 201-995 to the perifusate of dispersed cells from tumors. A comparison was made between the data obtained in preoperative tests for GH secretion and those obtained in experiments in vitro. Before operation, the GRF test $(100 \mu \mathrm{g}$, iv) resulted in no GH response in three of six patients examined. The CRF test $(100 \mu \mathrm{g}$, iv) resulted in a paradoxical GH increase in two of the same six patients. In vitro studies performed on adenoma cells revealed that exposure to GRF $(100 \mathrm{ng} / \mathrm{ml})$ elicited an increase in $\mathrm{GH}$ in seven of eight patients examined. Exposure to CRF $(100 \mathrm{ng} / \mathrm{ml})$ caused an enhanced $\mathrm{GH}$ secretion in four of the same eight patients. There were cases in which GH response to these hypothalamic hormones was observed in vitro but not in vivo, whereas there was only one case in which $\mathrm{CRF}$ caused an increase in GH in vivo but not in vitro. Thus, GH secretory dynamics was not always the same in vivo and in vitro. The discrepancy could be ascribed to the different secretory status of hypothalamic hormone (e.g., GRF or somatostatin) in vivo in each acromegalic patient.
\end{abstract}

In patients with acromegaly the secretory pattern of $\mathrm{GH}$ is often different from that of the normal. Recently, a paradoxical increase in plasma $\mathrm{GH}$ in response to intravenous CRF, in addition to that caused by TRH and LHRH, was reported (Pieters et al., 1984a). With respect to GRF, GH response is not always the same as in the normal. Decreased response of plasma $\mathrm{GH}$

Received April 22, 1988 or no response to GRF administered iv is frequently reported, though $\mathrm{GH}$ is increased either to the same as, or to a greater extent than the normal in the majority of the acromegalics (Wood et al., 1983, Shibasaki et al., 1984, von Werder et al., 1984, Pieters et al., 1984b, Gelato et al., 1985, Arosio et al., 1985). These abnormalities in GH secretion could be due to either a change in the hypothalamic regulatory mechanism (hypothalamic hor- 
mones and/or amines) for GH secretion, the disappearance of, or aberrant appearance of, receptors for these hypothalamic hormones at the pituitary level, and/or a change in the postreceptor mechanism.

In this study secretory responses of $\mathrm{GH}$ to GRF and CRF were examined in vitro in pituitary adenomas from acromegalics, and a comparison was made with those obtained in loading tests for $\mathrm{GH}$ secretion before operation. It was the purpose of this study to determine to what extent $\mathrm{GH}$ secretion in vitro can reflect secretion in vivo, and to get further insight into the mechanism underlying abnormal GH secretion in acromegalic patients.

\section{Materials and Methods}

\section{Patients}

Eight patients (aged 37-60 yr) with active acromegaly were examined in this study. All these patients had clinical features characteristic of acromegaly, viz. elevated plasma GH and somatomedin-C, or lack of $\mathrm{GH}$ suppression after oral administration of $100 \mathrm{~g}$ glucose. The clinical and biochemical data for the eight patients are summarized in Table 1. All of these patients underwent transsphenoidal surgery and a pituitary adenoma, which was confirmed histologically, was resected successfully in every case.

\section{Tests on $G H$ secretion}

Before operation, tests of GH secretory dynamics were performed. These included GRF and CRF tests $(100 \mu \mathrm{g}$, both) performed on separate occasions in six patients. The tests were started by administering these agents iv as a bolus at $800 \mathrm{~h}$ after an overnight fast and rest for $60 \mathrm{~min}$. Human GRF and human CRF were purchased from the Protein Institute (Osaka, Japan). Before the tests, an indwelling needle for administration of test substances and blood collection was inserted into a forearm vein and kept open by a slow $0.9 \%$ saline infusion. Plasma was separated and stored at $-30^{\circ} \mathrm{C}$ until assay. When plasma $\mathrm{GH}$ was increased by $50 \%$ above the basal level at least in two samples within $60 \mathrm{~min}$ after injection, it was judged as an increase (positive response).

\section{Cell culture}

Pituitary adenoma tissues obtained at transsphenoidal surgery were minced and then enzymatically dispersed with collagenase, Dispase and DNase according to Ceda et al (Ceda et al., 1985). Dispersed adenoma cells were then cultured for four to five days until used in Eagle's minimum essential medium (EMEM) supplemented with $10 \%$ fetal calf serum at $37^{\circ} \mathrm{C}$ in an atomosphere of $95 \%$ air and $5 \% \mathrm{CO}_{2}$.

Table 1. Clinical and biochemical data for 8 patients with active acromegaly

\begin{tabular}{cccccc}
\hline $\begin{array}{c}\text { Patient } \\
\text { no }\end{array}$ & Sex & $\begin{array}{c}\text { Age } \\
(\mathrm{yr})\end{array}$ & $\begin{array}{c}\text { Plasma GH } \\
(\mathrm{ng} / \mathrm{ml})\end{array}$ & $\begin{array}{c}\text { Somatomedin-C } \\
(\mathrm{U} / \mathrm{ml})\end{array}$ & Histology of adenoma \\
\hline 1 & $\mathrm{~F}$ & 59 & 64.4 & - & acidophilic \\
2 & $\mathrm{M}$ & 54 & 32.0 & 3.11 & acidophilic \\
3 & $\mathrm{M}$ & 55 & 31.7 & - & acidophilic \\
4 & $\mathrm{M}$ & 46 & 34.5 & 1.67 & acidophilic \\
5 & $\mathrm{M}$ & 37 & 36.7 & 4.04 & acidophilic \\
6 & $\mathrm{~F}$ & 60 & 33.2 & - & acidophilic \\
7 & $\mathrm{M}$ & 59 & 40.1 & 3.94 & acidophilic \\
8 & $\mathrm{M}$ & 35 & 17.7 & 3.08 & acidophilic \\
Mean & & 50.6 & 36.3 & 3.17 & \\
\pm SE & & 3.6 & 4.6 & 0.42 & \\
\hline
\end{tabular}

The mean of several determinations is shown.

In patient 1 , plasma PRL is also increased $(67.8 \mathrm{ng} / \mathrm{ml})$.

- ; not determined. 
Table 2. GH responses to GRF in vivo and in vitro

\begin{tabular}{|c|c|c|c|c|c|c|}
\hline \multirow[b]{2}{*}{ Patient } & \multicolumn{2}{|c|}{ In vivo } & \multirow[b]{2}{*}{ Response } & \multicolumn{2}{|c|}{ In vitro } & \multirow[b]{2}{*}{ Response } \\
\hline & $\begin{array}{c}\text { Basal GH } \\
\text { (ng/ml) }\end{array}$ & $\begin{array}{c}\text { Peak GH } \\
\text { (ng/ml) }\end{array}$ & & $\begin{array}{c}\text { Basal GH } \\
\text { (ng/fract) }\end{array}$ & $\begin{array}{r}\text { Peak GH } \\
\text { (ng/fract) }\end{array}$ & \\
\hline 1 & 74.3 & $415.1(558)$ & + & 8.3 & $18.6(224)$ & $t$ \\
\hline 2 & 34.4 & $193.4(562)$ & + & 7.1 & $16.2(228)$ & + \\
\hline 3 & - & - & & 13.6 & $25.7(188)$ & + \\
\hline 4 & 19.2 & $26.8(139)$ & - & 7.2 & 16,1 (223) & + \\
\hline 5 & 39.2 & $48.0(124)$ & - & 24.4 & $38.3(156)$ & + \\
\hline 6 & - & - & & 17.5 & $18.7(106)$ & - \\
\hline 7 & 38.7 & $42.0(108)$ & - & 11.7 & $21.5(182)$ & + \\
\hline 8 & 13.4 & $24.5(182)$ & + & 6.6 & $11.5(174)$ & + \\
\hline
\end{tabular}

In patients 3 and $6, \mathrm{GRF}$ test was not performed preoperatively. A GH increase to more than $50 \%$ over the basal was judged as a positive response, + , and that less than $50 \%$ as negative, - - ( ); \% of basal GH.

\section{Perifusion experiments}

Perifusion experiments were performed on eight adenomas. A perifusion column was prepared with a syringe and the volume of the perifusion chamber was adjusted to $1.0 \mathrm{ml}$. As a perifusion medium, Krebs-Ringer bicarbonate buffer containing $0.2 \%$ glucose and $0.1 \%$ bovine serum albumin was used. The medium was bubbled with $95 \% \mathrm{O}_{2}$ and $5 \% \mathrm{CO}_{2}$ throughout the experiments. About $4 \times 10^{6}$ cells were gently mixed with Sephadex G-10 previously equilibrated with the medium in the column according to the method described by Gillies and Lowry (Gillies and Lowry., 1978) with a modification. The flow rate was $0.5 \mathrm{ml} / \mathrm{min}$. The system was allowed to equilibrate for $2 \mathrm{~h}$ before the start of effluent collection, and $1.5 \mathrm{ml}$ fractions were collected at $3 \mathrm{~min}$ intervals. In vitro $\mathrm{GH}$ secretory dynamics was evaluated by adding to the perifusate CRF $(100 \mathrm{ng} / \mathrm{ml})$, GRF (1 or 100 $\mathrm{ng} / \mathrm{ml}$ ), and a somatostatin analog, SMS 201$995(100 \mathrm{ng} / \mathrm{ml}$, Sandoz, Switzerland) alone or in combination as a pulse of $4 \mathrm{ml}(8 \mathrm{~min})$ in random order. In addition to these agents, VIP, LHRH and TRH were also added, though these data are not shown for simplification. Intervals between pulses were approximately $60 \mathrm{~min}$. At the end of each experiment the cells were exposed to a pulse of concentrated $\mathrm{K}(50 \mathrm{mM})$ in order to determine the viability of the perifused cells. The effluents were stored at $-30^{\circ} \mathrm{C}$ until assay for $\mathrm{GH}$. The mean of $\mathrm{GH}$ concentrations in several fractions immediately before a pulse was regarded as the basal level.
When the GH concentration exceeded $150 \%$ of the basal level at an appropriate time after a pulse, it was judged as an increase (positive response).

\section{Hormone assays}

Plasma GH and the amount of GH in the effluent were determined by radioimmunoassay as reported previously (Maeda et al., 1976). GH was kindly provided by Dr. A. Parlow (National Pituitary Agency) and Dr. H. G. Friesen (University of Manitoba, Canada).

All the samples from a given experiment were run in the same assay. Intra- and interassay coefficients of variation were both less than $10 \%$.

\section{Results}

\section{In vivo $G H$ secretory dynamics}

The GRF test was performed in six acromegalic patients. GRF elicited a positive response (an increase) in plasma $\mathrm{GH}$ in three, but a negative response in plasma GH in the other three of six patients (Table 2). Plasma GH was increased from a basal level of $73.3 \mathrm{ng} / \mathrm{ml}$ to $415.1 \mathrm{ng} / \mathrm{ml}$, from $34.4 \mathrm{ng} / \mathrm{ml}$ to $193.4 \mathrm{ng} / \mathrm{ml}$ and from $13.4 \mathrm{ng} / \mathrm{ml}$ to $24.5 \mathrm{ng} / \mathrm{ml}$ in patients 1,2 and 8 , respectively. The CRF test was also performed in the same six patients. 
Table 3. GH responses to $\mathrm{CRF}$ in vivo and in vitro

\begin{tabular}{|c|c|c|c|c|c|c|}
\hline \multirow[b]{2}{*}{ Patient } & \multicolumn{2}{|c|}{ In vivo } & \multirow[b]{2}{*}{ Response } & \multicolumn{2}{|c|}{ In vitro } & \multirow[b]{2}{*}{ Response } \\
\hline & $\begin{array}{c}\text { Basal GH } \\
(\mathrm{ng} / \mathrm{ml})\end{array}$ & $\begin{array}{c}\text { Peak GH } \\
(\mathrm{ng} / \mathrm{ml})\end{array}$ & & $\begin{array}{l}\text { Basal GH } \\
\text { (ng/fract) }\end{array}$ & $\begin{array}{r}\text { Peak GH } \\
\text { (ng/fract) }\end{array}$ & \\
\hline 1 & 46.9 & $84.8(180)$ & + & 8.9 & $9.2(103)$ & - \\
\hline 2 & 18.5 & $48.5(262)$ & + & 7.6 & $18.2(239)$ & + \\
\hline 3 & & - & & 14.4 & 16.7 (115) & - \\
\hline 4 & 19.7 & $19.9(101)$ & - & 8.1 & 19.8 (244) & + \\
\hline 5 & 36.3 & $40.3(110)$ & - & 26.2 & $53.4(203)$ & + \\
\hline 6 & - & - & & 17.5 & $19.3(110)$ & - \\
\hline 7 & 38.9 & $41.5(106)$ & - & 10.3 & 19.4 (188) & + \\
\hline 8 & 16.4 & 21.1 (128) & - & 7.4 & $6.5(101)$ & - \\
\hline
\end{tabular}

In patients 3 and 6 , the CRF test was not performed preoperatively. A GH increase to more than $50 \%$ over the basal was judged as a positive response, + , and that less than $50 \%$ as negative, -

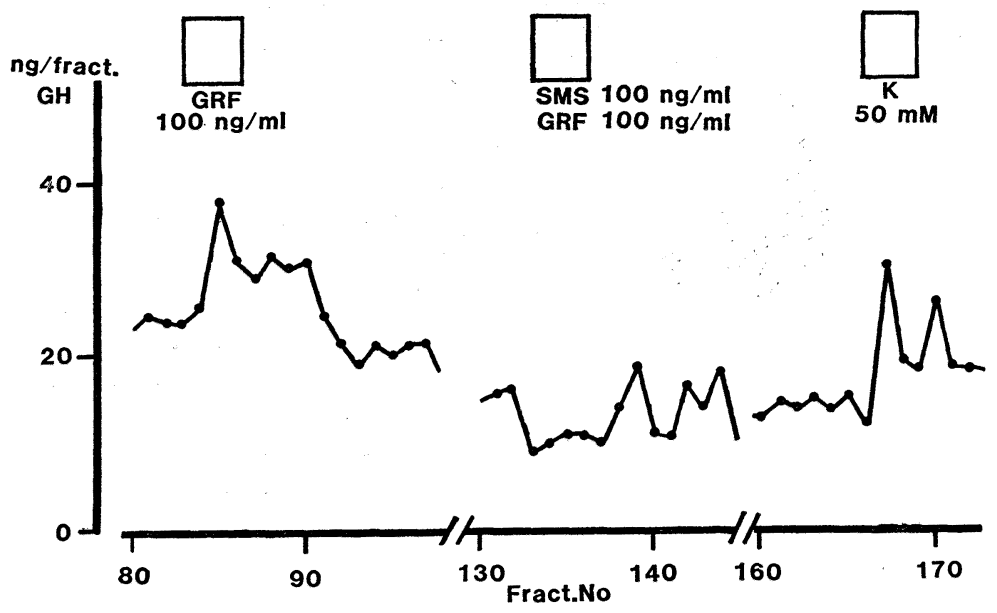

Fig. 1. Effect of GRF, SMS 201-995 and 50 $\mathrm{mM} \mathrm{K}^{+}$on $\mathrm{GH}$ secretion from somatotroph adenoma in vitro. Results for patient 5 are shown.

$\mathrm{CRF}$ administration resulted in a $\mathrm{GH}$ increase in two patients (Table 3). In contrast to responses to GRF, CRF elicited a smaller GH increase. Plasma GH levels changed from $46.9 \mathrm{ng} / \mathrm{ml}$ to $84.8 \mathrm{ng} / \mathrm{ml}$ and from $18.5 \mathrm{ng} / \mathrm{ml}$ to $48.5 \mathrm{ng} / \mathrm{ml}$ in patients 1 and 2 , respectively, both of whom also responded to GRF.

\section{In vitro $G H$ secretory dynamics}

In a preliminary experiment, after an equilibration period of $2 \mathrm{~h}$, basal GH levels were stable without marked spontaneous fluctuations throughout the experiment. At the end of the experiments, the addition of $50 \mathrm{mM} \mathrm{K}^{+}$elicited a burst increase in $\mathrm{GH}$ in every case, indicating that the cells were viable for the period (Fig. 1).

The effect of GRF on GH release in vitro was examined in all of the eight cases. The GH concentration was increased in response to GRF $(100 \mathrm{ng} / \mathrm{ml})$ in seven cases (Table 2). The increases were to approximately twice the basal level and peaked approximately $5 \mathrm{~min}$ after the beginning of the pulse. $\mathrm{GH}$ returned to the 
basal level approximately $15 \mathrm{~min}$ after the end of the pulse. GRF at a lower dose $(1 \mathrm{ng} / \mathrm{ml})$ also elicited an increase in $\mathrm{GH}$ in the perifusate in these seven cases. A representative change in the $\mathrm{GH}$ concentration in response to $100 \mathrm{ng} / \mathrm{ml} \mathrm{GRF}$ is shown in Fig. 1.

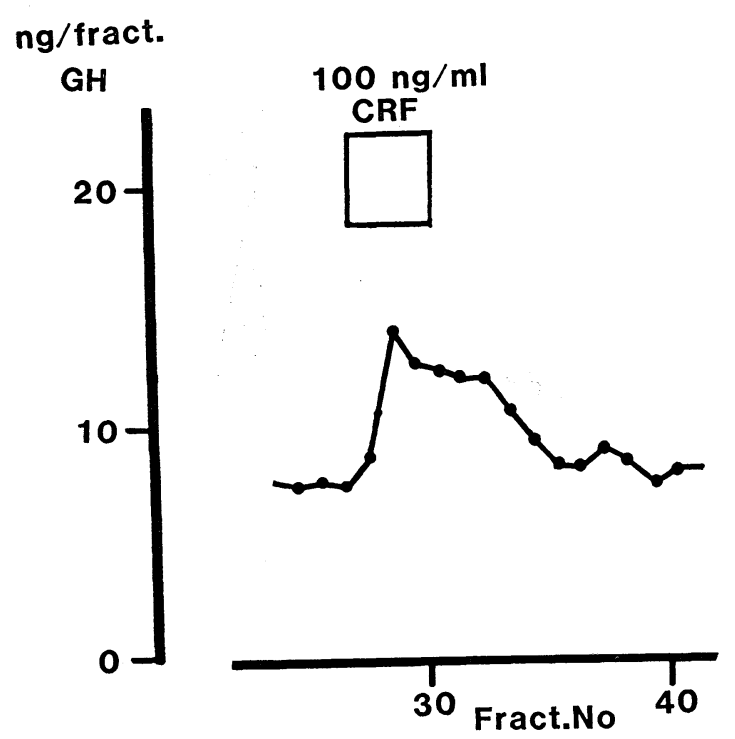

Fig. 2. Effect of CRF on GH secretion from a somatotroph adenoma in vitro. Results for patient 2 are shown.

The effect of CRF was examined in eight cases in vitro. A GH increase was elicited in four of eight cases in response to CRF (100 ng/ml) (Table 3). The magnitude and time course of the GH increase were comparable with those of GRF (Fig. 2). Whenever an increase in $\mathrm{GH}$ was elicited by CRF, a GH response to GRF was also observed in vitro.

In some cases an increase in $\mathrm{GH}$ was elicited in vitro but not in vivo by GRF (Patients 4, 5 and 7, Table 2). It was probable that a $\mathrm{GH}$ increase to be caused by GRF was inhibited by endogenous somatostatin in vivo in these cases. Therefore, SMS 201-995 $(100 \mathrm{ng} / \mathrm{ml})$ was added simultaneously with GRF $(100 \mathrm{ng} / \mathrm{ml})$ to the perifusate in cases 4,5 and 7 ; to evaluate the sensitivity of these adenomas to somatostatin. In these three cases, an increase in GH, which was caused by GRF alone, was abolished completely by simultaneous administration of SMS 201-995. Further, $\mathrm{GH}$ was increased over the basal level 15 min after the termination of simultanous exposure to SMS 201-995 and GRF (Fig.1).

On the other hand, an increase in $\mathrm{GH}$ was induced in vivo but not in vitro by CRF in patient 1 (Table 3 ). It is possible that endogenous GRF sensitized the adenoma to exogenous in vivo $\mathrm{CRF}$ resulting in a $\mathrm{GH}$ increase. Therefore, the effect of CRF $(100 \mathrm{ng} / \mathrm{ml})$ in the presence of GRF administered continuously at a low dose (1 $\mathrm{ng} / \mathrm{ml}$ ) was examined in case 1. GRF (1 $\mathrm{ng} / \mathrm{ml}$ ) caused a $\mathrm{GH}$ increase, which peaked $15 \mathrm{~min}$ after the beginning of the pulse and declined thereafter despite its continued presence. However, CRF added during the

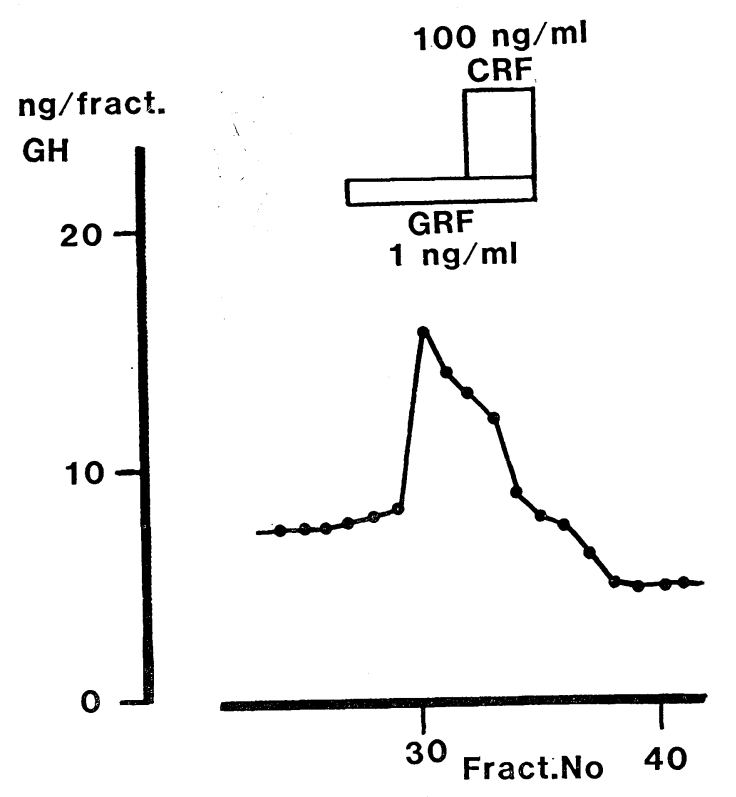

Fig. 3. Effect of CRF on GH secretion from a somatotroph adenoma in the presence of GRF in a lower dose in vitro. Results for Patient 1 are shown. 
latter half of GRF exposure did not effect a further decline in the $\mathrm{GH}$ concentration (Fig. 3).

In some cases (Patients 4, 5 and 7) an increase in $\mathrm{GH}$ due to $\mathrm{CRF}$ was elicited in vitro but not in vivo (Table 3). It was probable that endogenous somatostatin inhibited the $\mathrm{GH}$ response to $\mathrm{CRF}$ in vivo As shown above, SMS 201-995 inhibited a GRF-induced GH increase when added to the perifusate simultaneously with GRF. However, the effect of SMS 201-995 on GH secretion induced by CRF was not examined.

\section{Discussion}

In this study a bolus iv injection of GRF, unexpectedly, did not cause an increase in $\mathrm{GH}$ in half of the patients (three of six patients). An increase in $\mathrm{GH}$ either to the same or a greater extent as in the normal has been reported in the majority of acromegalics. In our patients the frequency of decreased or no response to GRF was higher than those reported previously (Wood et al., 1983, Shibasaki et al., 1984, von Werder et al., 1984, Pieters et al., 1984b, Gelato et al., 1985, Arosio et al., 1985).

The reduced or no GH response to GRF in acromegalics could be due to a change in the hypothalamic regulatory mechanism, disappearance of GRF receptor in the pituitary, or changes in the postreceptor mechanism. In addition, it has been reported that GH response to GRF is usually suppressed in patients with an ectopic GRFproducing tumor, a rare form of acromegaly (Schulte et al., 1985). Although increased GH in this study was due to a pituitary adenoma in each case, excessive hypothalamic GRF might have been responsible for no or decreased $\mathrm{GH}$ response to exogenous GRF.

In this study GRF elicited a GH increase in vitro in seven of eight patients.
Thus, the in vivo frequency of negative $\mathbf{G H}$ response was much higher than that observed in vitro. This type of discrepancy might be explained by a factor(s) which interferred with $\mathrm{GH}$ response to GRF in vivo. First, endogenous GRF in excess might have suppressed $\mathrm{GH}$ response to exogenous GRF in vivo as mentioned above. However, a definite conclusion cannot be formed until the GRF in the portal system can be measured accurately. Second, endogenous somatostatin in excess might be responsible. Endogenous somatostatin might be increased as a result of feedback in a group of acromegalic patients. In this group, an excess of endogenous somatostatin would interfere with $\mathrm{GH}$ response to GRF, as long as an adenoma was sensitive to somatostatin. To evaluate this possibility, an analog of somatostatin, SMS 201-995, which was demonstrated to bind specifically to somatostatin receptors in human pituitary (Reubi and Landolt, 1984), was used in vitro in this study. An increase in $\mathrm{GH}$ caused by GRF $(100 \mathrm{ng} / \mathrm{ml})$, was abolished completely simultaneous administration of SMS 201-995 (100 ng/ml) with GRF, indicating that these adenomas were sensitive to somatostatin. However, no definite conclusion on the possible involvement of endogenous somatostatin can be drawn until the somatostatin concentration in the portal blood is measured.

In this study CRF administered iv as a bolus elicited an increase in $\mathrm{GH}$ in two of six acromegalics. An increase in plasma $\mathrm{GH}$ in response to CRF has been also reported in acromegalics (Pieters et al., 1984a) and in patients with primary affective disorders (Gold et al., 1983). The frequency of a paradoxical increase in $\mathrm{GH}$ in response to CRF in this study was comparable to that in acromegalic reported previously (Pieters et al., 1984a), but much lower than that caused by TRH (Faglia et al., 1973a).

The paradoxical increase caused by CRF 
might also be ascribed to a change in the hypothalamic regulatory mechanism (e.g., contribution of GRF exposure to GH increase by TRH, Sartorio et al., 1986), the aberrant appearance of receptor for CRF in somatotrophs (Pieters et al., 1984a) as postulated for the mechanism of paradoxical responses by TRH and LHRH (Faglia et al., 1973a, Faglia et al., 1973b, Matsukura et al., 1977) or changes in the postreceptor mechanism. The finding reported by Pieters et al., (1984a) might indicate that basal GH levels determine responsiveness to CRF. In this study, basal GH was high in one and low in another responsive patient. Taken together, these data suggest that the basal $\mathrm{GH}$ level is not a major determinant of $\mathrm{GH}$ responsiveness to CRF.

In response to $\mathrm{CRF}$, an increase in $\mathrm{GH}$ was elicited both in vivo and in vitro in one patient proving the site of CRF action on the pituitary (Patient 2). In another patient an increase in $\mathrm{GH}$ was induced in vivo but not in vitro by CRF (patient 1). 1t was possible that endogenous GRF sensitized the adenoma to exogenous CRF in this patient as postulated for paradoxical GH response to TRH (Thorner et al., 1982, Schulte et al., 1985). Therefore, the effect of CRF $(100 \mathrm{ng} / \mathrm{ml})$ was examined in the presence of GRF in a low dose $(1 \mathrm{ng} / \mathrm{ml})$ administered continuously. CRF, added during the latter half of GRF exposure, did not induce a $\mathrm{GH}$ response, though GRF (1 ng/ml) alone caused a GH increase. The size of the tumor did not allow us to further examine various conditions such as the use of different doses of GRF and CRF, and timing of CRF addition. Therefore, it might be premature to draw a conclusion on the possible involvement of endogenous GRF in this patient.

The frequency of positive $\mathrm{GH}$ response to CRF in vitro was also higher than that observed in vivo. CRF elicited a GH increase in four of eight patients in vitro, but in only two of six patients in vivo This discrepancy might be due to the fact that endogenous somatostatin interferred with a $\mathrm{GH}$ increase in response to $\mathrm{CRF}$ in vivo as mentioned above in connection with $\mathrm{GH}$ response to GRF. However, the effect of somatostatin or SMS 201-995 on the CRFinduced $\mathrm{GH}$ increase was not examined in these cases because of the limited size of tumor amount available.

The discrepancy between $\mathrm{GH}$ responses in vivo and in vitro to GRF or CRF in this study suggests that the involvement of endogenous somatostatin and/or GRF in the regulation of $\mathrm{GH}$ secretion in acromegalics might be qualitatively different from patient to patient. The so-called paradoxical GH response in patients with acromegaly might reflect the secretory status of these hypothalamic hormones in vivo. In order to further verify this hypothesis it is necessary to evaluate the level of these hypothalamic hormones in the portal blood directly or indirectly.

\section{Acknowledgements}

This work was supported in part by a grant from the Smoking Research Foundation, the Grant-in-Aid for Scientific Research from the Japanese Ministry of Education, Science and Culture, and a grant for Intractable Diseases from the Japanese Ministry of Health and Welfare.

We thank Drs. H. G. Friesen and A. Parlow for their generous gifts of high purity human GH.

\section{References}

Arosio, M., B. Ambrosi, L. Guglielmino and O. Faglia (1985). Human pancreatic growth hormone-releasing factor (hp GRF-44) in acromegaly before and after adenomectomy. Modifications induced by somatostatin (GHRIH) infusion. J. Endocrinol. Invest. 8, 449-453.

Ceda, G. P., A. R. Hoffman, G. D. Silevrberg, D. M. Wilson and R. G. Rosenfeld 
(1985). Regulation of growth hormone release from cultured human pituitary adenomas by somatomedins and insulin. J. Clin. Endocrinol. Metab. 60, 1204-1209.

Faglia, O., P. Beck-Peccoz, C. Ferrari, P. Travaglini, B. Ambrosi and A. Spada (1973a). Plasma growth hormone response to thyrotropin-releasing hormone in patients with active acromegaly. J. Clin. Endocrinol. Metab. 36, 1259-1262.

Faglia, O., P. Beck-Peccoz, C. Travaglini, A. Paracchi, A. Spada and A. Lewin (1973b). Elevations in plasma growth hormone concentration after luteinizing hormone-releasing hormone (LRH) in patients with active acromegaly. J. Clin. Endocrinol Metab. 37, 338-344.

Gelato, M. C., G. R. Merriam, M. L. Vance, J. A. Goldman, C. Webb, W. S. Evans, J. Rock, E. M. Oldfield, M. E. Molitch, J. River, W. Vale, S. Reichlin, L. A. Frohman, D. L. Loriaux and M. O. Thorner (1985). Effects of growth hormone releasing factor on growth hormone secretion in acromegaly. J. Clin. Endocrinol. Metab. 60, 251-257.

Gillies, G. and P. J. Lowry (1978). Perfused rat isolated anterior pituitary cell column as bioassay for factor(s) controlling release of adrenocorticotropin release. Endocrinology 103, 521-525.

Gold, P., C. Kellner, D. Rubinow, M. Altemus and R. Post (1983). Abnormal growth hormone responses to corticotropin-releasing factor in patients with primary affective disorders. Program of the 65th Annual Meeting of The Endocrine Society, San Antonio, TX (Abstract 443) p. 191.

Maeda, K., Y. Kato, S. Ohgo, K. Chihara, Y. Yoshimoto, N. Yamaguchi, S. Kuromaru and H. Imura (1976). Growth hormone release following thyrotropin releasing hormone injection into patients with anorexia nervosa. Acta. Endocrinol. (Copenh) 81, 1-3.

Matsukura, S., T. Kakita, Y. Hirata, H. Yoshimi, M. Fukase, Y. Iwasaki, Y. Kato and H. Imura (1977). Adenylate cyclase of $\mathrm{GH}$ and ACTH producing tumor of human: activation by non-specific hormones and other bioactive substances. J. Clin. Endocrinol. Metab. 44. 392-397.

Pieters, G. F., A. R. Hermus, A. G. H. Smals and P. W. C. Kloppenborg (1984a). Paradoxical responsiveness of growth hormone to corticotropin-releasing factor in acromegaly.
J. Clin. Endocrinol. Metab. 58, 560-562.

Pieters, G. F., A. E. Smals, A. R. Hermus, A. G. H. Smals, T. H. J. Benraad and P. W. C. Kloppenborg (1984b). Growth hormone responsiveness to human pancreatic growth hormone releasing factor in acromegaly: modulatory effects of basal hormone levels and concomitant somatostatin administration. Clin. Endocrinol. (Oxf) 21, 701-707.

Reubi, J. C. and M. A. Landolt (1984). High density of somatostatin receptors in pituitary tumors from acromegalic patients. J. Clin. Endocrinol. Metab. 56, 1148-1151.

Sartorio, A., A. Spade, D. Bochicchio, A. Atterato, F. Morabito and G. Faglia (1986). Effect of thyrotropin-releasing hormone on growth hormone release in normal subjects pretreated with human pancreatic growth hormone-releasing factor 1-44 pulsatile administration. Neuroendocrinology 44, 470-474.

Schulte, H. M., G. Benker, R. Windeck, T. Olbricht and D. Reinwein (1985). Failure to respond to growth hormone releasing hormone (GHRH) in acromegaly due to a GHRH secreting pancreatic tumor: dynamics of multiple endocrine testing. J. Clin. Endocrinol. Metab. 61, 585-587.

Shibasaki, T., K. Shizume, A. Masuda, M. Nakahara, N. Hizuka, M. Miyakawa, K. Takano, H. Demura, I. Wakabayashi and N. Ling (1984). Plasma growth hormone response to growth hormone-releasing factor in acromegalic patients. J. Clin. Endocrinol. Metab. 58, 215-217.

Thorner, M. O., R. L. Perryman, M. J. Cronin, A. D. Rogol, M. Draznin, A. Johanson, W. Vale, E. Horvath and K. Kovacs (1982). Somatotroph hyperplasia; successful treatment of acromegaly by removal of pancreatic islet tumor secreting a growth hormone-releasing factor. J. Clin. Invest. 70, 965-977.

von Werder, K., O. A. Muller, R. Hartl, M. Losa and G. K. Stalla (1984). Growth hormone releasing factor (hpGRF)-stimulation test in normal controls and acromegalic patients. J. Endocrinol. Invest. 7, 185-191.

Wood, S. M., J. L. C. Ch'ng, F. Adams, J. D. Webster, G. F. Joplin, K. Mashiter and S. R. Bloom (1983). Abnormalities of growth hormone release in response to human pancreatic growth hormone releasing factor (GRF1-44) in acromegaly and hypopituitarism. Br. Med. J. 286, 1687-1691. 